\title{
Host specificity of four corallivorous Phestilla nudibranchs (Gastropoda: Opisthobranchia)
}

\author{
Raphael Ritson-Williams ${ }^{1,2, *}$, Sonia Shjegstad ${ }^{1}$, Valerie Paul ${ }^{1,2}$ \\ ${ }^{1}$ University of Guam Marine Laboratory, UOG Station, Mangilao, Guam 96923, USA \\ ${ }^{2}$ Present address: Smithsonian Marine Station at Fort Pierce, 701 Seaway Drive, Fort Pierce, Florida 34949, USA
}

\begin{abstract}
Nudibranchs that exclusively eat scleractinian corals provide a rare opportunity to study specialist predation in the marine environment. To measure the diet breadth of 4 Phestilla species on Guam, we offered the nudibranchs different corals in choice and no-choice feeding assays. Larval preferences were determined by measuring the percent metamorphosis in response to different coral species. We compared the specificity of larval metamorphosis to adult feeding preferences. Phestilla sibogae ate a range of Porites species (Poritidae) in the field and would not eat other coral genera in the laboratory no-choice assays. Metamorphosis was approximately $90 \%$ in response to 4 Porites spp. Phestilla minor was found on Porites lutea and Porites annae in the field. It preferred $P$. annae over Porites cylindrica and $P$. (Synaraea) rus during the choice and no-choice assays. The highest rates of metamorphosis (approx. $80 \%$ ) were in response to P. lutea, P. annae, and P. cylindrica. Phestilla sp. 1 is morphologically similar to $P$. minor, but it eats different Porites species. It preferred $P$. (S.) rus, but would eat $P$. cylindrica during the no-choice assays. The highest rate of metamorphosis (approx. $80 \%$ ) was in response to $P$. (S.) rus. Phestilla sp. 2 is distinct from the other Phestilla species studied, as it is a specialist on corals in the genus Goniopora (Poritidae). It preferred G. fruticosa and also ate G. minor and G. lobata during the feeding assays. The highest rates of metamorphosis (approx. $60 \%$ ) were in response to G. fruticosa, G. minor, and G. lobata. This study documents a range of diet breadth among Phestilla species. Phestilla spp. larvae could distinguish between coral species within a host genus and showed a tendency to have high metamorphosis on their preferred hosts, but they also metamorphosed in response to non-food coral species.
\end{abstract}

KEY WORDS: Phestilla $\cdot$ Host specialization $\cdot$ Coral predators $\cdot$ Larval metamorphosis

\section{INTRODUCTION}

The evolution of host specificity has intrigued ecologists for the last century (Berenbaum 1996). A narrow dietary breadth (defined as feeding on 1 family of plants for insects) requires the evolution of a suite of adaptations, which limits the resources a consumer can use to survive. Insects are well-studied in terms of their dietary breadth and the ecological factors thought to determine specialization (Futuyma \& Moreno 1988). Predation, resource partitioning, and host-plant chemistry have been proposed as important factors favoring the close association between insects and their host plants (Bernays \& Graham 1988, Schultz 1988).
In the marine environment there are fewer specialists, and these are typically associated with a smaller range of host species as compared to terrestrial ecosystems (Hay et al. 1990, Hay 1992, Hay \& Steinberg 1992). Among the best examples of marine specialists are opisthobranch mollusks, including sacoglossans and nudibranchs. Over $80 \%$ of the sacoglossan gastropods are specialist herbivores (Hay 1992, Williams \& Walker 1999). Nudibranchs in the genus Phestilla prey exclusively on scleractinian corals (Harris 1975, Rudman 1981). Adult Phestilla sibogae (= Phestilla lugubris, Rudman 1981) feed on Porites compressa (Poritidae) in Hawaii (Hadfield 1977) and on Porites somaliensis and Phestilla australensis in the Indian 
Ocean (Tanzania) (Rudman 1981). In Tanzania, $P$. minor was also found on Porites somaliensis and $P$. australensis. Phestilla melanobrachia feeds on multiple coral genera in the Dendrophyllidae throughout the Indo-Pacific (Harris 1975). In addition to these 3 described Phestilla species, 2 additional species are found feeding on Porites spp. (Poritidae) and Goniopora spp. (Poritidae) in Guam, a region of relatively high coral diversity (Randall 2003).

Phestilla species, like many marine gastropods, have planktonic larvae that settle and metamorphose in response to chemical cues from sessile prey organisms (Hadfield 1977, Lambert \& Todd 1994, Krug \& Manzi 1999, Trowbridge 2000). In Hawaii, a small (<500 MW), polar, water-soluble molecule released from Porites compressa is required for metamorphosis of Phestilla sibogae (Hadfield \& Pennington 1990). Without this chemical cue, $P$. sibogae will not metamorphose from a planktonic veliger to a juvenile slug. This obligate relationship between Phestilla spp. and their coral hosts provides an opportunity to study dietary breadth of these nudibranchs in terms of adult and larval specificity.

In the present study, we examined the host specificity of 4 species of Phestilla found on Guam. We determined whether adult feeding choice and larval metamorphosis correspond to preferred prey. Three aspects of specificity were measured: (1) adult distributions on different species of corals in the field, (2) adult consumption of different corals, and (3) larval metamorphosis in response to different corals. In addition to our studies with $P$. sibogae and $P$. minor, we report specificity data for 2 additional species of Phestilla that are currently being described (B. Rudman pers. comm.).

\section{MATERIALS AND METHODS}

Species studied. Phestilla sibogae is an aeolid nudibranch described by Bergh in 1905. This species was synonymized under the name $P$. lugubris by Rudman (1981). However, there is evidence that there are 2 closely related species of Phestilla in the eastern tropical Pacific as well as 2 available names, P. sibogae and $P$. lugubris (M. Hadfield pers. comm.). We use the name $P$. sibogae to be consistent with the last $25 \mathrm{yr}$ of published research on this species. This species grows to a length of approximately $30 \mathrm{~mm}$ and is characterized by cerata covered with irregular nodules ending in a swollen rounded tip (Rudman 1981). The color of the cerata is variable depending on coral host species. $P$. sibogae lays a spiral white egg ribbon with lecithotrophic veliger larvae that are competent for metamorphosis $4 \mathrm{~d}$ after hatching (=9 d after fertilization)
(Miller \& Hadfield 1986). P. sibogae is widely distributed throughout the Indo-Pacific (Harris 1975, Rudman 1981).

Phestilla minor (Rudman 1981) can reach a length of $7 \mathrm{~mm}$ and has cerata with a swollen distal tip and 1 swollen collar region below this (Rudman 1981). This species has been recorded from Tanzania, Australia, and Hawaii (Rudman 1981). P. minor has an average of $44.1 \pm 4.59$ (mean $\pm \mathrm{SE}, \mathrm{n}=18$ ) eggs in each oval egg mass that are either straight or curved in the shape of a semicircle. The larvae are lecithotrophic and are competent to metamorphose immediately after hatching (5 to $6 \mathrm{~d}$ post-fertilization) (S.S. unpubl. data).

Phestilla sp. 1 resembles P. minor, but it has morphological characteristics that may be an indication of sibling speciation. Phestilla sp. 1 reaches a maximum length of $5 \mathrm{~mm}$ and has cerata with 1 swollen region below a tapering distal tip. It produces $24.4 \pm 1.27$ (mean $\pm \mathrm{SE}, \mathrm{n}=18$ ) eggs per oval egg mass, and has lecithotrophic larvae with immediate metamorphic competence after hatching (see 'Results').

Phestilla sp. 2 is similar in size and morphology to $P$. sibogae and reaches a maximum length of $30 \mathrm{~mm}$. It has smooth cerata that taper and end in a distal swollen bulb. Phestilla sp. 2 has a yellow egg ribbon which is layed in a spiral. Its lecithotrophic larvae are competent for metamorphosis after a 4 d larval stage (9 d post-fertilization) (R.R.-W. unpubl. data). This species has been briefly mentioned as a specialist on corals in the genus Goniopora, and has been observed in Singapore and Papua New Guinea (Robertson 1970, Gosliner 1992, Gosliner et al. 1996).

Field surveys. Field surveys were conducted using SCUBA or snorkeling at a total of 29 sites on Guam $\left(13^{\circ} \mathrm{N}, 144^{\circ} \mathrm{E}\right)$, from 18 January to 5 October 2001. More sites were searched on the western side of the island, because rough seas prevail on the eastern side during most of the year. Field surveys were also conducted at 8 sites in the Republic of Palau $\left(7^{\circ} \mathrm{N}\right.$, $133^{\circ} \mathrm{E}$ ), from 1 to 10 August 2002. Habitats searched included the reef flat and the fore-reef slope from 0 to $20 \mathrm{~m}$.

To minimize damage to corals, only fragments and small loose colonies of corals were examined for nudibranchs, which limited the ability to search large coral heads. Corals were turned over and visually searched for adult Phestilla. No attempt was made to quantify the population densities of nudibranchs, since only small coral colonies were searched and small juvenile nudibranchs could not be seen. At each location, the species of Phestilla and the coral it was found on were recorded. If a coral species was unknown, a small sample was brought back to the laboratory for identification. Coral voucher specimens are kept at the University of Guam Marine Laboratory. 
Adult feeding assays. Adult nudibranchs were raised in laboratory aquaria on host corals. Larvae were raised to metamorphic competence (see below), and were then placed in $10.8 \mathrm{l}$ plastic containers with their host coral in aerated standing seawater. To ensure the same feeding history of all Phestilla sibogae used for assays, adults were raised on Porites (Synaraea) rus. Phestilla minor and Phestilla sp. 1 were brought from the field on fragments of Porites annae and $P$. (S.) rus, respectively. Due to the rarity of Phestilla sp. 2, it was also raised in the laboratory, on Goniopora fruticosa. Water was changed in each container every 3 d until juvenile Phestilla spp. were observed. The nudibranchs were then moved to flowthrough seawater containers and allowed to feed until they reached an adult size.

The dietary preference of adult Phestilla spp. was tested using choice assays in laboratory aquaria. The assays were run for $72 \mathrm{~h}$, because the nudibranchs would begin to die after $72 \mathrm{~h}$ without feeding. Individual adult Phestilla spp. were maintained in $600 \mathrm{ml}$ plastic containers with flow-through seawater and offered fragments (2 to $6 \mathrm{~cm}$ long) of 2 different species of coral. Coral fragments were checked for feeding scars, and the cumulative number of polyps eaten was recorded every $24 \mathrm{~h}$. Containers with the same size and species of corals without nudibranch predators were used to control for autogenous changes in the number of polyps. Separate assays were run in which Phestilla sibogae was offered a choice of Porites cylindrica versus Turbinaria reniformis, and $P$. cylindrica versus Goniopora fruticosa. Phestilla minor was offered $P$. cylindrica versus Porites annae, and Porites (S.) rus versus $P$. annae. Phestilla sp. 1 was offered a choice between $P$. (S.) rus versus $P$. annae, and $P$. cylindrica versus $P$. (S.) rus. Phestilla sp. 2 was offered $P$. cylindrica versus $G$. fruticosa, and $G$. fruticosa versus $G$. minor. These coral species were chosen to determine if there was an overlap of preferred prey among each Phestilla species. Coral fragments and individual nudibranchs were only used once in feeding trials.

No-choice assays were conducted to determine if Phestilla species would eat other corals in the absence of preferred hosts. The assays were set up as described for the choice assays except that each nudibranch was maintained with 1 coral fragment. Each species of Phestilla was offered the same coral species that were used during the choice assays. Phestilla sp. 2 was also offered Goniopora lobata and G. eclipsensis during the no-choice assays. The cumulative number of coral polyps consumed was recorded every $24 \mathrm{~h}$ for $72 \mathrm{~h}$. All feeding values are reported as cumulative means \pm 1 standard error (SE).

Larval metamorphosis assays. Adults were maintained in the laboratory to provide a source of eggs.
Adult nudibranchs and live coral fragments were collected from various locations around Guam and maintained in flow-through seawater outdoor aquaria. A total of 5 to 20 adult nudibranchs were supplied with host corals that served as food as well as a substrate for egg deposition. Approximately 10 egg masses were collected from the corals 5 to $6 \mathrm{~d}$ after deposition, checked microscopically for complete development (as indicated by fully formed, moving veligers), and artificially hatched in petri dishes by ripping the egg cases with a pair of forceps.

Larvae were raised to metamorphic competence. Newly hatched veligers from different egg masses were combined and transferred from the petri dishes to 2-4 larval chambers constructed as described by Miller \& Hadfield (1986). These PVC chambers were placed in 11 plastic beakers and filled with antibioticspiked seawater $\left(90 \mu \mathrm{g}\right.$ penicillin $\mathrm{G} \mathrm{ml}^{-1}$, and $75 \mu \mathrm{g}$ streptomycin sulfate $\mathrm{ml}^{-1}$ ). Antibiotic-spiked seawater was changed daily, and beakers were placed in a running seawater bath to maintain ambient ocean temperature (approx. 28 to $32^{\circ} \mathrm{C}$ ). The larvae were not fed in the chambers. The length of time in the larval chambers varied from $1 \mathrm{~d}$ for Phestilla minor to $4 \mathrm{~d}$ for $P$. sibogae and Phestilla sp. 2. In separate assays, larval metamorphosis was tested after 0,1 , and $2 \mathrm{~d}$ for Phestilla sp. 1.

Larval metamorphosis was tested in response to different coral species. For each metamorphosis assay, 10 to 50 larvae were transferred to individual $5 \mathrm{ml}$ wells (Phestilla minor and Phestilla sp. 1) or $9 \mathrm{ml}$ wells (P. sibogae and Phestilla sp. 2) of Costar $^{\circledR}$ media culture well-plates (nos. 3513 and 3516). Many assays had a low number of replicates ( 3 to 5 ) due to the limited number of larvae available from each culture. Treatments of 1 coral fragment in $3 \mathrm{ml}$ of $0.2 \mu \mathrm{m}$ filtered seawater (FSW) or the control (only FSW) were added to the individual wells with the larvae. Corals were broken into 1 - to 2 -cm pieces at least $24 \mathrm{~h}$ prior to the assays. The third assay with Phestilla sp. 2 used larger 3 -cm coral fragments in $100 \mathrm{ml}$ glass beakers, which were filled with FSW to a total volume of $50 \mathrm{ml}$. Coral species were selected for these assays if they were eaten by the adult Phestilla spp. or found in the same habitat as host coral species.

The proportion of larval metamorphosis was scored for each treatment. The culture plates were checked for the proportion of larvae that had metamorphosed after $24 \mathrm{~h}$ for Phestilla sibogae and after $48 \mathrm{~h}$ for the 3 other species. Larvae of $P$. sibogae lose their shells as they metamorphose from the veliger stage into a juvenile slug within $24 \mathrm{~h}$ of exposure to the chemical cue produced by Porites spp. (Hadfield 1977). The other 3 species had the highest percentage of metamorphosis after $48 \mathrm{~h}$ of exposure to host corals. Although small 
juvenile slugs were observed in the wells, it was more precise to count the empty shells than the transparent juveniles. Percent metamorphosis was calculated as the number of empty shells/total number of larvae $\times$ 100. Larvae not metamorphosed after $48 \mathrm{~h}$ were considered unaffected by the coral treatments.

The proportion of metamorphosis was analyzed for significant differences using ANOVA followed by a Tukey (HSD) post-hoc test. If data did not meet the assumptions of ANOVA, they were arcsine-transformed, or the non-parametric Kruskal-Wallis test was used followed by a procedure comparing mean ranks. All figures show untransformed data. All analyses were conducted using Statistix 7 (Analytical Software).

\section{RESULTS}

\section{Field surveys}

In the field on Guam, Phestilla sibogae was found on 6 species of Porites (Table 1). It was most commonly found on Porites lutea and P. (S.) rus in reef-flat and fore-reef-slope habitats on both sides of Guam (Fig. 1). Phestilla minor was found on 2 species of coral, Porites annae and P. lutea, on both sides of Guam. Phestilla sp. 1 was found on Porites cylindrica or P. (S.) rus on reef flats and fore-reef slopes on both sides of Guam. Phestilla sp. 2 was only found on Goniopora fruticosa at 2 locations on the fore-reef slope on the eastern side of Guam, even though this coral is found on both sides of the island. Phestilla sibogae, P. minor, and Phestilla sp. 1 were found sympatrically at 5 reefs that are dominated by multiple species of Porites. P. minor and Phestilla sp. 1 were consistently found on distinct Porites species (Table 1). Phestilla species were not observed at 12 sites that typically had low coral cover or few host species (Fig. 1).

On Palau, Phestilla sibogae was found on 4 species of Porites (Table 1). Phestilla minor was only found on Porites lutea; however, Porites annae was rarely encountered. Phestilla sp. 1 was found on both Porites cylindrica and $P$. (S.) rus. Phestilla sp. 2 was only found on Goniopora djiboutiensis, but G. fruticosa was never observed.

\section{Adult feeding assays}

During the laboratory choice experiments, Phestilla sibogae only consumed Porites cylindrica (Fig. 2a,b). During the no-choice assays, $P$. sibogae ate $P$. cylindrica and a small amount of Turbinaria reniformis (Fig. 3a-c). No coral polyp mortality was observed in the controls, except for $5.6 \pm 3.4$ (mean \pm SE) P. cylindrica polyps dead in the no-choice assay, after $72 \mathrm{~h}$.

Phestilla minor strongly preferred Porites annae in both choice assays (Fig. 2c,d). During the choice assays, in only 1 replicate, 4 Porites cylindrica and 2 Porites (S.) rus polyps were consumed. Only P. annae was eaten during the no-choice assays (Fig. 3-f). No coral polyps were found dead in the control containers.

Phestilla sp. 1 only ate Porites (S.) rus during the choice assays (Fig. 2e,f). During the no-choice assay

Table 1. Phestilla spp. Summary of host preferences for Phestilla nudibranchs (G: Guam; P: Palau)

\begin{tabular}{|c|c|c|c|}
\hline & $\begin{array}{l}\text { Coral species eaten } \\
\text { in the field }\end{array}$ & $\begin{array}{l}\text { Coral species eaten } \\
\text { in the laboratory }\end{array}$ & $\begin{array}{l}\text { Larval metamorphosis, } \\
\text { preferred corals }^{\mathrm{a}}\end{array}$ \\
\hline Phestilla sibogae & $\begin{array}{l}\text { Porites annae }(\mathrm{G}, \mathrm{P}) \\
\text { P. australiensis }(\mathrm{G}) \\
\text { P. cylindrica }(\mathrm{G}, \mathrm{P}) \\
\text { P. lutea }(\mathrm{G}, \mathrm{P}) \\
\text { P. }(\text { S.) rus }(\mathrm{G}, \mathrm{P}) \\
\text { P. vaughni }(\mathrm{G})\end{array}$ & Porites cylindrica & $\begin{array}{l}\text { Porites annae } \\
\text { P. cylindrica } \\
\text { P. lutea } \\
P .(\text {. }) \text { rus }\end{array}$ \\
\hline Phestilla minor & $\begin{array}{l}\text { Porites annae }(\mathrm{G}) \\
\text { P. lutea }(\mathrm{G}, \mathrm{P})\end{array}$ & Porites annae & $\begin{array}{l}\text { Porites annae } \\
\text { P. cylindrica } \\
\text { P. lutea } \\
\text { Turbinaria reniformis }\end{array}$ \\
\hline Phestilla sp. 1 & $\begin{array}{l}\text { Porites cylindrica }(\mathrm{G}, \mathrm{P}) \\
\text { P. }(\text { S. }) \text { rus }(\mathrm{G}, \mathrm{P})\end{array}$ & $\begin{array}{l}\text { Porites cylindrica } \\
\text { Porites (S.) rus }\end{array}$ & $\begin{array}{l}\text { Porites }(S .) \text { rus } \\
\text { P. annae }\end{array}$ \\
\hline Phestilla sp. 2 & $\begin{array}{l}\text { Goniopora fruticosa }(\mathrm{G}) \\
\text { G. djiboutiensis }(\mathrm{P})\end{array}$ & $\begin{array}{l}\text { Goniopora fruticosa } \\
\text { G. lobata } \\
\text { G. minor }\end{array}$ & $\begin{array}{l}\text { Goniopora fruticosa } \\
\text { G. lobata } \\
\text { G. minor } \\
\text { Porites cylindrica }\end{array}$ \\
\hline
\end{tabular}




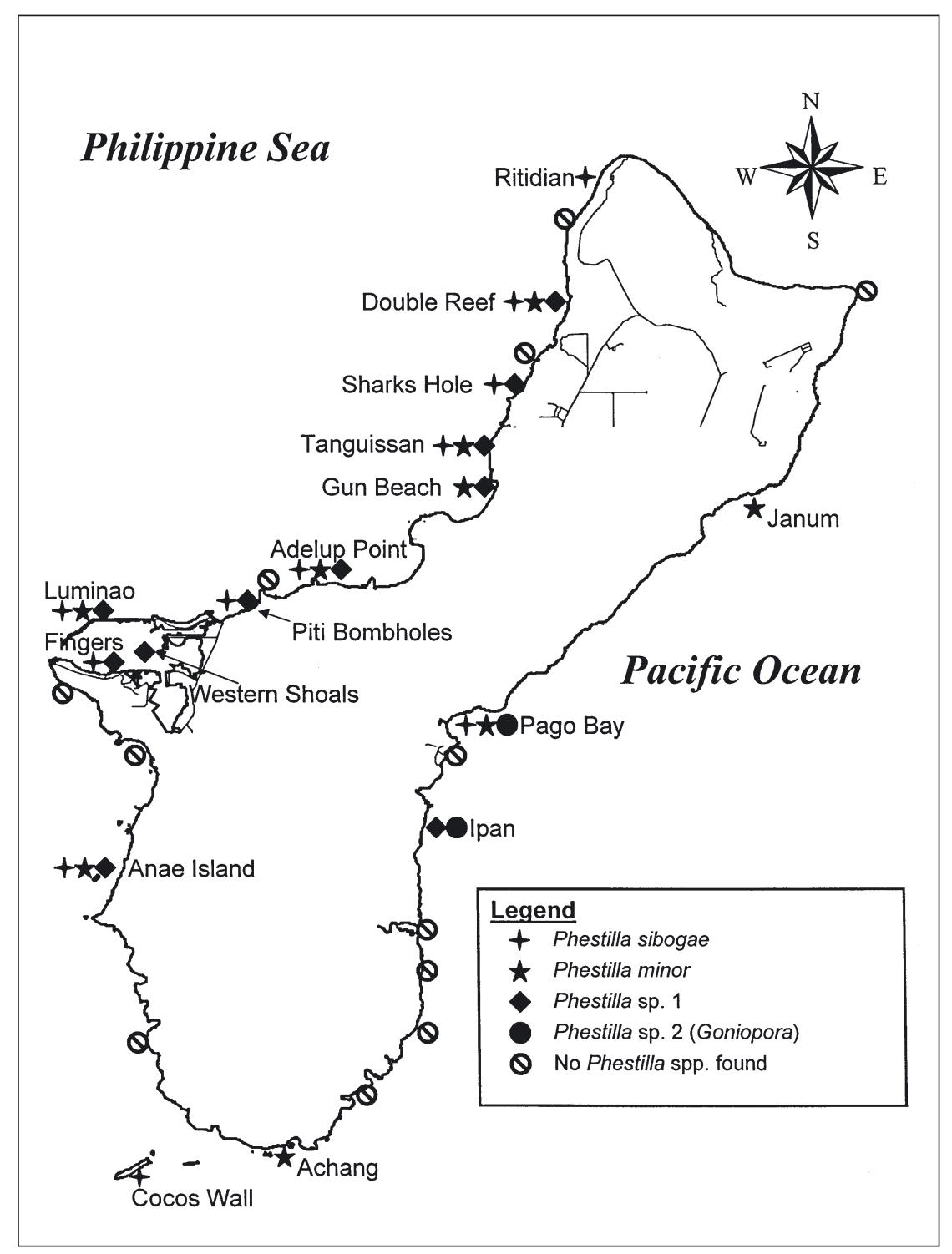

Fig. 1. Phestilla spp. Distribution of 4 Phestilla species on Guam. Symbols indicate locations where at least 1 adult Phestilla sp. was observed. At each location small coral colonies and fragments were inspected for Phestilla spp. Guam was searched between 18 January and 5 October 2001

Phestilla sp. 1 ate approximately 9 P. (S.) rus polyps and 4 P. cylindrica polyps after $72 \mathrm{~h}$ (Fig. $3 \mathrm{~g}-\mathrm{i})$. There was no consumption of $P$. annae. There was no coral polyp mortality in the controls.

Phestilla sp. 2 ate Goniopora fruticosa and G. minor, but not Porites cylindrica during the choice assays (Fig. 2g,h). It consumed G. fruticosa, G. minor, and G. lobata polyps, but would not feed on P. cylindrica or Goniopora eclipsensis during the no-choice assays (Fig. 3j-n). In the controls during the no-choice assays $1.8 \pm 0.8$ G. fruticosa and $3.4 \pm 3.4(\mathrm{n}=5)$ P. cylindrica polyps were dead after $72 \mathrm{~h}$. There was no mortality for the other coral controls.

\section{Larval metamorphosis assays}

Phestilla sibogae had $>90 \%$ metamorphosis in response to Porites annae and P. cylindrica (KruskalWallis, p < 0.001) (Fig. 4a); however, means were not significantly different from those of Turbinaria reniformis and Goniopora fruticosa. In the second assay, all 4 Porites species induced high percentages of metamorphosis (Kruskal-Wallis, p < 0.001) (Fig. 4b). In both assays there was 40 to $60 \%$ metamorphosis in response to T. reniformis, which was not significantly different from the filtered seawater (FSW) control in either assay (Fig. 4a,b). 
a. Phestilla sibogae $(n=4)$

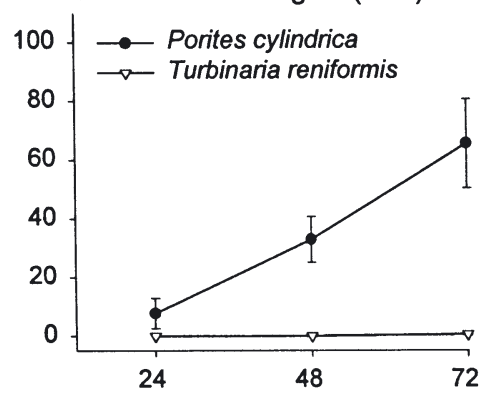

c. Phestilla minor $(n=5)$

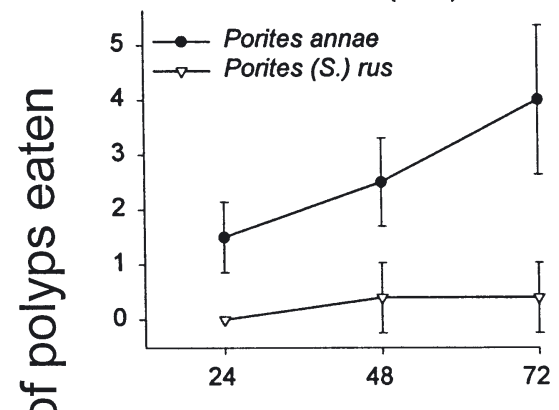

e. Phestilla sp. $1(n=5)$

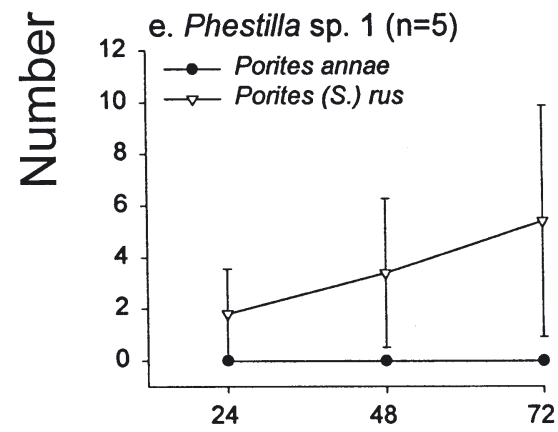

g. Phestilla sp. $2(n=4)$

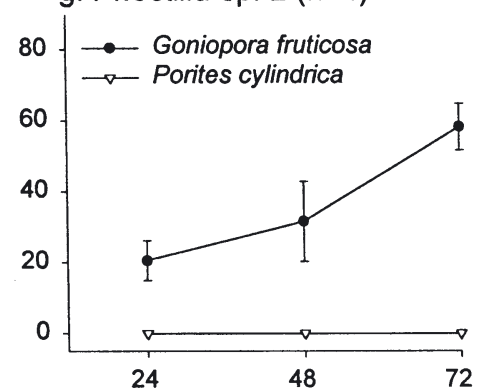

b. Phestilla sibogae $(n=4)$

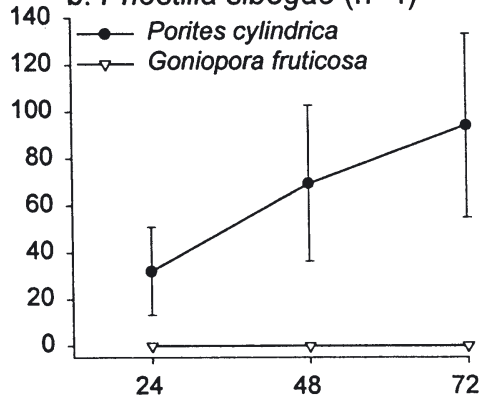

d. Phestilla minor $(n=5)$

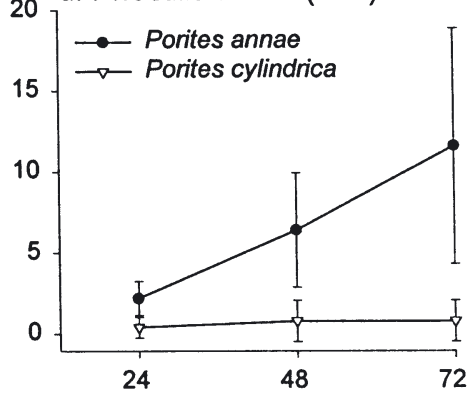

f. Phestilla sp. $1(n=4)$

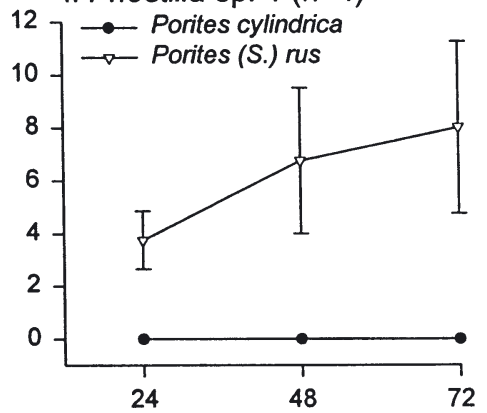

h. Phestilla sp. $2(n=5)$

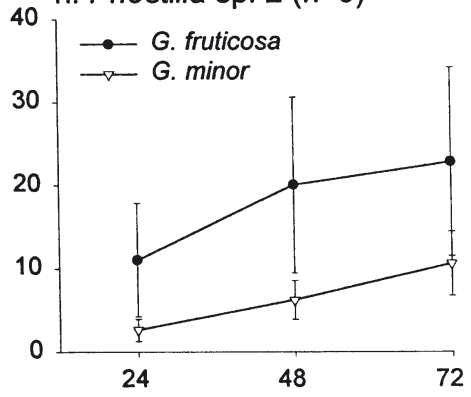

Hours

Fig. 2. Phestilla spp. Feeding choices of individual Phestilla spp. adults when offered both species of corals simultaneously. Graphs show the mean cumulative number of coral polyps eaten every $24 \mathrm{~h}$ for $72 \mathrm{~h}$. Error bars are \pm 1 SE. No mortality in control corals was observed; these data are not shown for clarity. Note different scales on individual graphs 

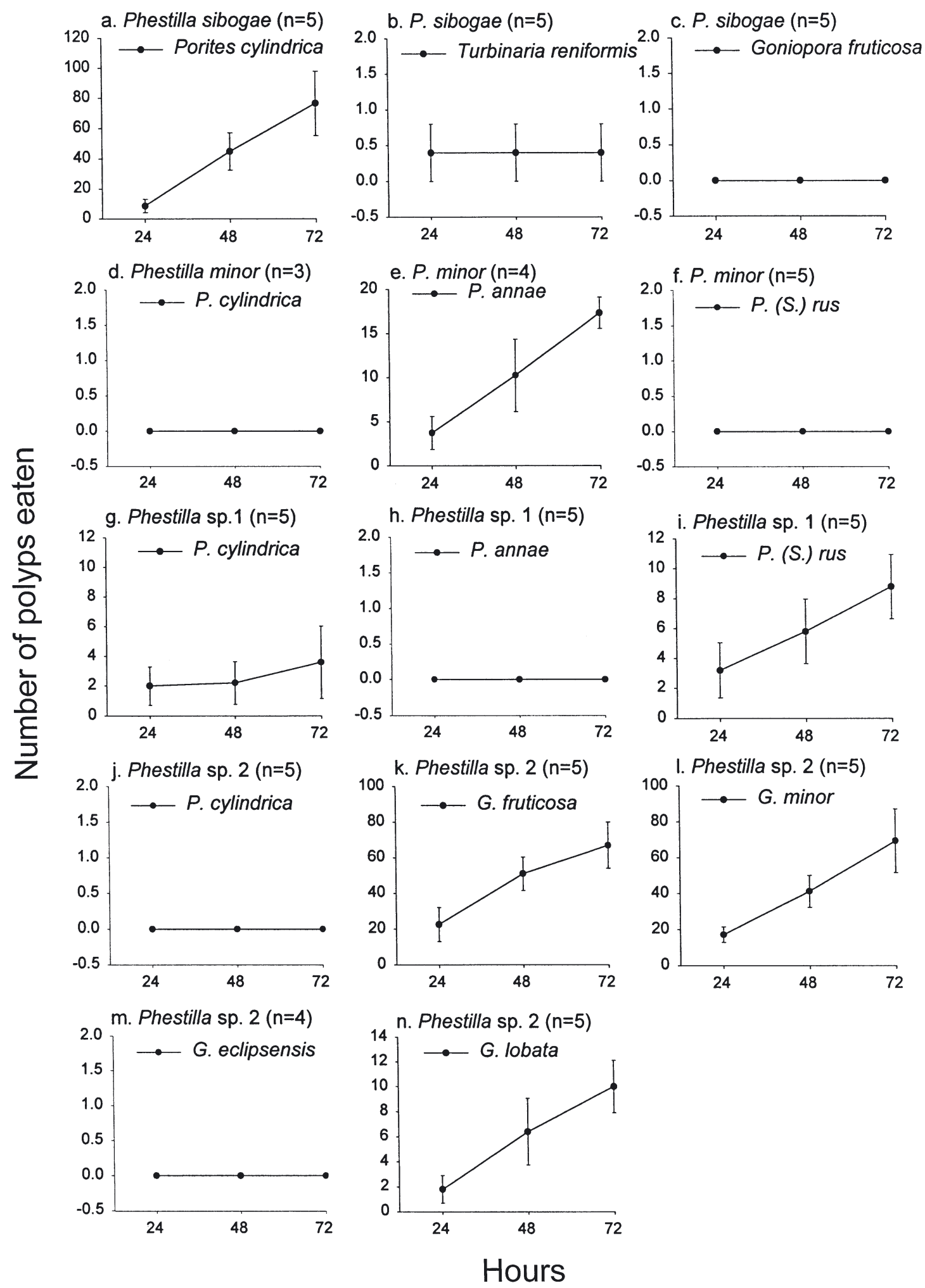

Fig. 3. Phestilla spp. Feeding of Phestilla spp. adults when no choices were offered. Graphs are the mean cumulative number of coral polyps eaten every $24 \mathrm{~h}$ for $72 \mathrm{~h}$. Error bars are \pm 1 SE. Polyp mortality in controls is not shown (see 'Results'). Note different scales on individual graphs 


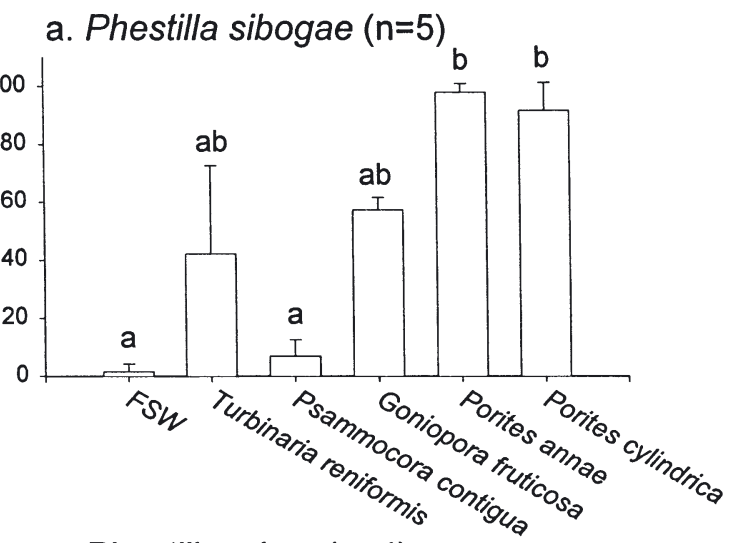

c. Phestilla minor $(n=4)$

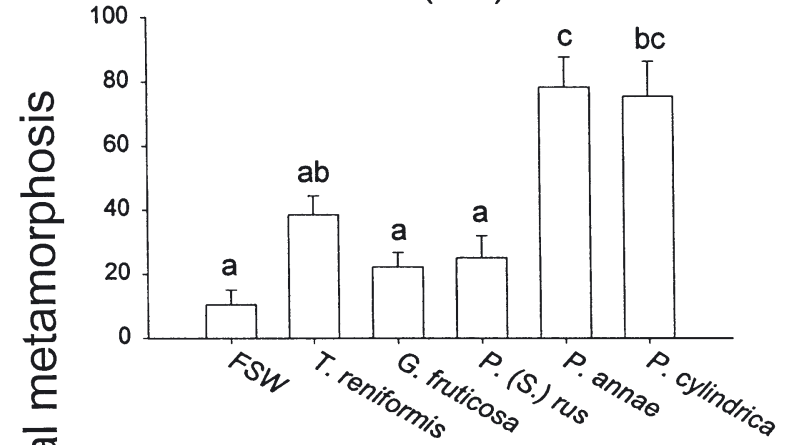

e. Phestilla sp. $1(n=4)$

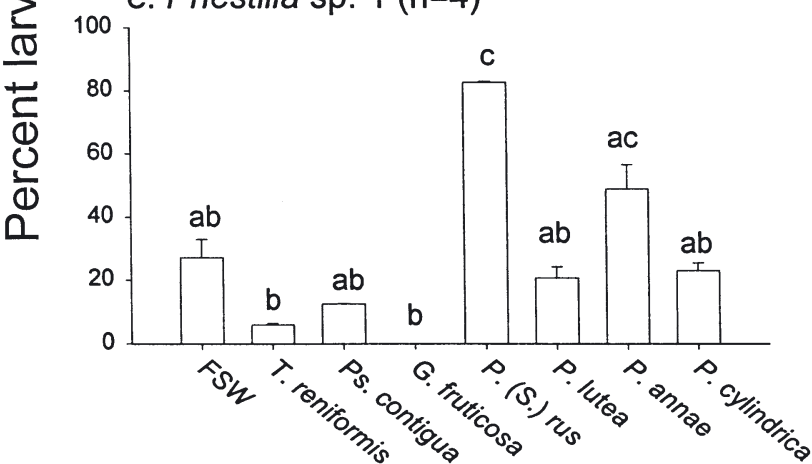

b. P. sibogae $(n=8)$

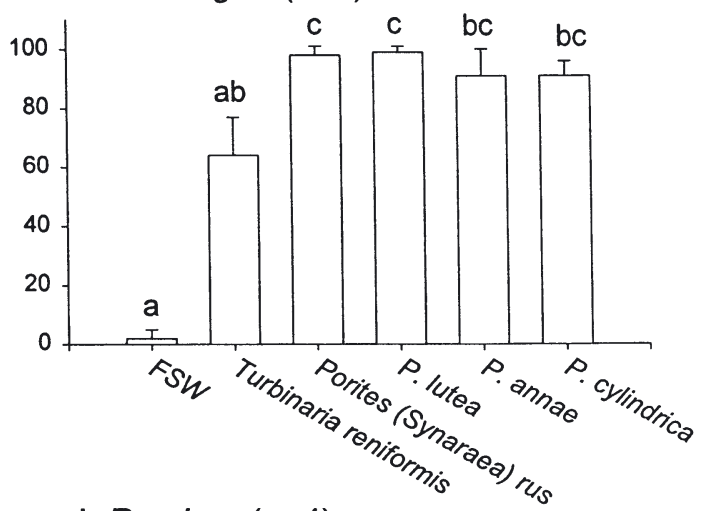

d. P. $\operatorname{minor}(\mathrm{n}=4)$

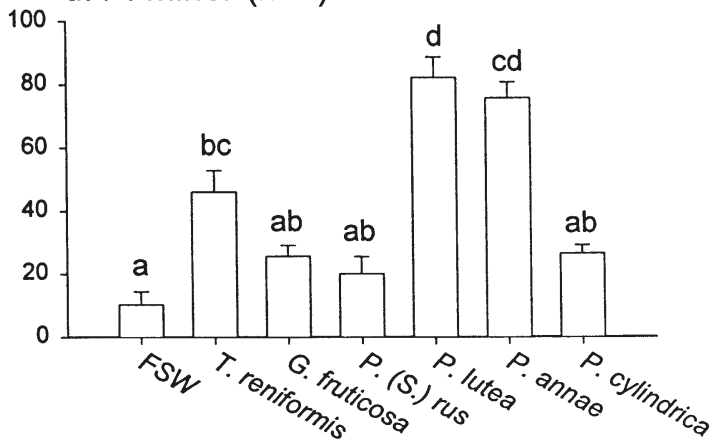

f. Phestilla sp. $1(n=3)$ g. Phestilla sp. 1
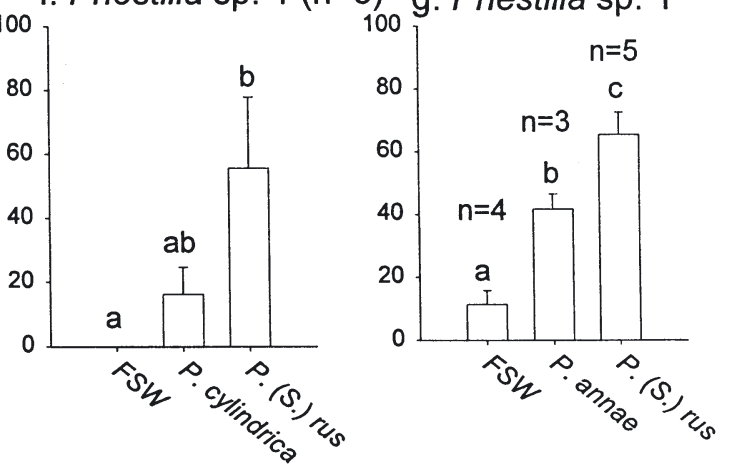

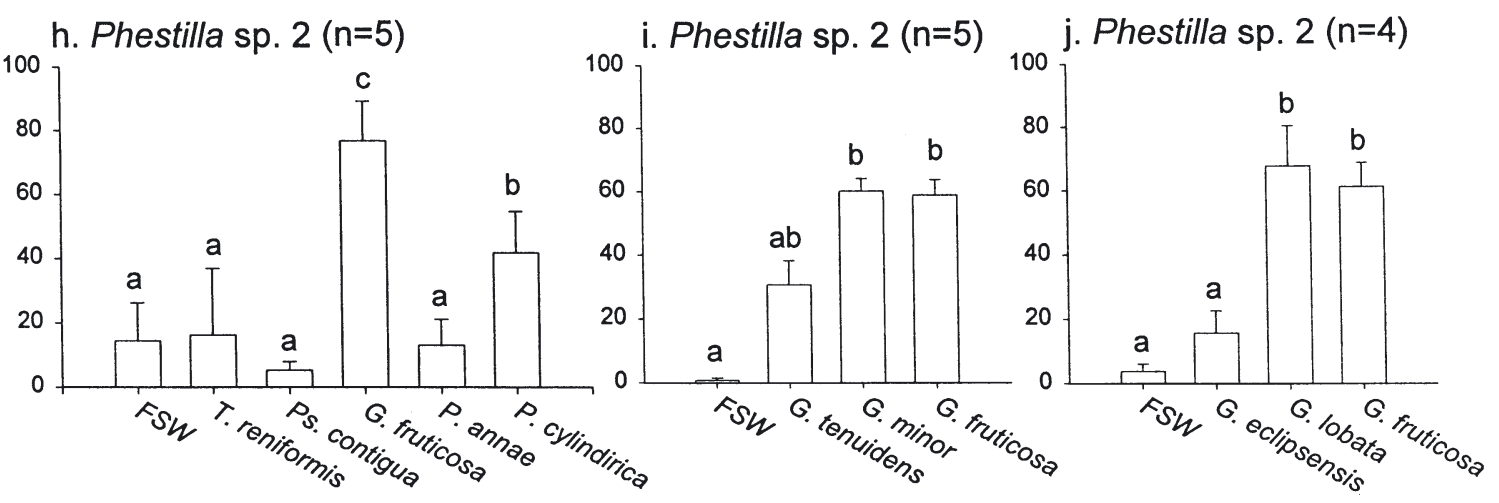

Coral species

Fig. 4. Phestilla spp. Larval metamorphosis in response to live coral fragments in 4 Phestilla species. Individual graphs are separate assays with different larval cultures. Bars represent mean percentage metamorphosis with $+1 \mathrm{SE}$. Controls are $0.2-\mu$ mfiltered seawater (FSW). Larval age varied for each species; $4 \mathrm{~d}$ after hatching for $P$. sibogae and Phestilla sp. 2, $1 \mathrm{~d}$ for $P$. minor, and 0,1 , and $2 \mathrm{~d}$ for Phestilla sp. $1 \mathrm{in} \mathrm{f,} \mathrm{e,} \mathrm{and} \mathrm{g,} \mathrm{respectively.} \mathrm{Mean} \mathrm{percentage} \mathrm{of} \mathrm{metamorphosis} \mathrm{was} \mathrm{measured} \mathrm{after} 24 \mathrm{~h}$ for $P$. sibogae or $48 \mathrm{~h}$ for P. minor, Phestilla sp. 1, and Phestilla sp. 2. Significant groupings are indicated by the letters above bars, analyses are by 1-way ANOVA or Kruskal-Wallis tests 
Phestilla minor had $80 \%$ metamorphosis in response to Porites annae and P. cylindrica (Fig. 4c). Metamorphosis on Porites (S.) rus and Goniopora fruticosa was less than that on $P$. annae and $P$. cylindrica (ANOVA, $\mathrm{p}<0.001)$. Metamorphosis on $P$. (S.) rus, T. reniformis, and $G$. fruticosa was not significantly different from the FSW control. Metamorphosis on P. cylindrica was as high as on $P$. annae in the first assay, but not the second (Fig. 4c,d). In the second assay Phestilla minor had greater metamorphosis in response to Porites lutea and $P$. annae than to $P$. (S.) rus and P. cylindrica (ANOVA, $\mathrm{p}<0.001)$. There was approximately $40 \%$ metamorphosis in response to $T$. reniformis, which was also significantly different from the FSW control. In both assays about $10 \%$ of the larvae metamorphosed in the FSW treatment (Fig. 4c,d).

In all 3 assays, Phestilla sp. 1 had the highest metamorphosis in response to Porites (S.) rus (ANOVA, $\mathrm{p}<0.001$ ) (Fig. 4e-g). The percentage of metamorphosis on $P$. (S.) rus was consistently higher than that on $P$. annae, and was significantly greater in the third assay (ANOVA, p < 0.001) (Fig. 4g). Metamorphosis in response to $P$. $(S$.) rus was significantly greater than that on $P$. cylindrica in the first assay (Fig. 4 e), but not in the second (Kruskal-Walllis, $\mathrm{p}=0.003$ ) (Fig. 4f). No change in the rates of metamorphosis 0,1 , or $2 \mathrm{~d}$ after hatching were observed for Phestilla sp. 1 (Fig. 4f,e, and g respectively). Metamorphosis on Porites lutea, P. cylindrica, Goniopora fruticosa, Turbinaria reniformis, and Psammacora contigua was not different from the FSW controls in any of the assays (Fig. $4 \mathrm{e}-\mathrm{g}$ ). Rates of spontaneous metamorphosis in the FSW controls were relatively high in some assays (Fig. 4e).

Metamorphosis in Phestilla sp. 2 was greatest in response to Goniopora fruticosa, but there was also approximately $40 \%$ metamorphosis to Porites cylindrica (ANOVA, p < 0.001) (Fig. 4h). The percentages of metamorphosis on Turbinaria reniformis, Psammacora contigua, and Porites annae were not different from the FSW control. In the second assay (Fig. 4i) there was high metamorphosis on G. minor and G. fruticosa. The congener $G$. tenuidens induced approximately $30 \%$ metamorphosis, but was not different from the FSW control (Kruskal-Wallis, $\mathrm{p}<0.001$ ). During the third assay, conducted in $100 \mathrm{ml}$ beakers, there was approximately $60 \%$ metamorphosis in response to G. lobata and G. fruticosa (ANOVA, p < 0.001) (Fig. 4j). G. eclipsensis induced only approximately $16 \%$ metamorphosis, which was not significantly different from the FSW control.

\section{DISCUSSION}

With over 400 species (from 21 families) of corals to choose from on Guam, larval settlement for Phestilla spp. is an important process that determines host availability for juveniles and adults. Survival of these nudibranchs is dependent upon finding the specific host corals that induce metamorphosis. With few exceptions (mentioned below), larval metamorphosis corresponded to adult feeding preferences (Table 1). Phestilla sibogae only ate Porites spp. (Poritidae) in the laboratory and the field, and had high rates of larval metamorphosis in response to all the Porites species tested. The chemical cue necessary for $P$. sibogae metamorphosis is produced by at least 4 species of Porites from Guam and Porites compressa on Hawaii. There was variable, but always less metamorphosis on Turbinaria reniformis (Dendrophyllidae) and Goniopora fruticosa (Poritidae). These 2 species are not eaten by $P$. sibogae, but $G$. fruticosa is preferred by Phestilla sp. 2. Our observations are consistent with previous records of $P$. sibogae eating and settling in response to Porites species (Harris 1973, Hadfield 1977, Rudman 1981). Due to the high diversity of coral species on Guam and Palau we are able to broaden the documented range of corals eaten by $P$. sibogae from the 3 Porites species previously recorded (Hadfield 1977, Rudman 1981) to at least 8 species.

In the field Phestilla minor was only found on Porites annae and $P$. lutea. In the laboratory this species preferred $P$. annae, and would not eat $P$. cylindrica and $P$. (S.) rus. Larval metamorphosis was highest in response to $P$. annae and P. lutea. P. minor had variable metamorphosis in response to $P$. cylindrica and Turbinaria reniformis, which may be a result of natural variation in the rates of metamorphosis among different batches of larvae (Wieczorek \& Todd 1998). There was also some spontaneous metamorphosis in the seawater controls (Fig. 4c,d: Shjegstad 2002). This has not been previously reported for $P$. minor, but is known to occur in some opisthobranchs (Gibson \& Chia 1995, Krug 2001). P. minor was found on Porites compressa in Hawaii and on $P$. somaliensis and $P$. australensis in Tanzania (Rudman 1981). New records of this species from different regions may broaden the number of preferred hosts; however, we observed similar levels of specificity on both Guam and Palau.

Phestilla sp. 1 is morphologically similar to P. minor, but it feeds on different coral species. Phestilla sp. 1 was found on Porites (S.) rus and P. cylindrica on both Guam and Palau, but preferred $P$. (S.) rus in the laboratory feeding assays. The highest metamorphosis was also on $P$. ( $S$. ) rus, but this was not consistently different from $P$. annae, which it would not eat. There was lower metamorphosis in response to $P$. cylindrica and $P$. lutea, which were not different from the FSW controls. Phestilla sp. 1 was found on P. cylindrica in the field, but did not prefer it in the laboratory assays. This sug- 
gests that $P$. cylindrica is not a preferred host, but this may be an indication of population level preferences, or conditioning, as the Phestilla sp. 1 in our assays were all raised on $P$. (S.) rus. After being raised on 1 host the opisthobranch might be physiologically acclimated, making it difficult to switch hosts during the laboratory assays (Hall et al. 1982, Trowbridge 1991). The distinct host utilization observed between $P$. minor and Phestilla sp. 1 is a characteristic of sibling species in both marine and terrestrial ecosystems (Feder \& Bush 1989, Knowlton 1993, 2000, Funk et al. 1995, Leebens-Mack et al. 1998). The short larval competence period for Phestilla sp. 1 and P. minor would imply less dispersal, potentially leading to resource partitioning of distinct Porites species.

Phestilla sp. 2 ate and metamorphosed on some of the Goniopora species, but not $G$. eclipsensis. It preferred G. fruticosa during the choice assays, but was observed by Gosliner et al. (1996) in Papua New Guinea on other Goniopora species. During the nochoice assays there was a similar amount of G. fruticosa and G. minor eaten, but less G. lobata; however, G. lobata has large polyps that probably provide more biomass than polyps of either G. fruticosa or $G$. minor. Why Phestilla sp. 2 did not eat all of the Goniopora species is unknown; however, rates of larval metamorphosis consistently matched adult feeding behavior.

The specificity of Phestilla melanobrachia on corals in the Dendrophyllidae was well studied by Harris $(1973,1975)$. P. melanobrachia has a wide dietary breadth of multiple genera in the Dendrophyllidae. $P$. minor and Phestilla sp. 1 ate 1 or 2 Porites species. P. sibogae eats at least 8 Porites species, indicating a broader dietary breadth than that of $P$. minor and Phestilla sp. 1. Adult dietary breadth of opisthobranchs is often thought to be specific to 1 genus or even 1 species of prey; however, field observations do not necessarily reveal their potential dietary breadth (Williams \& Walker 1999, Ginsburg \& Paul 2001). Our field observations of Phestilla sp. 2 on Guam suggested that it only ate Goniopora fruticosa. We found that it would eat 2 other Goniopora species in the laboratory, which is potentially important for survival in habitats with little or no G. fruticosa, such as the areas searched in Palau.

Many marine larvae use chemotaxis to locate the appropriate host organisms (Pawlik 1992, ZimmerFaust \& Tamburri 1994, Morse et al. 1996, Williamson et al. 2000, Browne \& Zimmer 2001). Phestilla sibogae requires a chemical cue produced by Porites compressa for metamorphosis from a planktonic veliger to a benthic slug (Hadfield \& Scheuer 1985, Hadfield \& Pennington 1990). Our results found that metamorphosis in the laboratory did not always match feeding preferences. Larvae metamorphosed at high rates on preferred coral species, but sometimes also metamorphosed in response to non-food corals. For example, Turbinaria reniformis and $P$. cylindrica induced significant metamorphosis in multiple Phestilla species that would not eat them. This may provide a potential mechanism for host switching in a dynamic community (Trowbridge \& Todd 2001); however, adult Phestilla from the field were not observed on these species, and our results may be an experimental artifact. Different species and genera of corals may have similar chemical cues or variable ratios of multiple cues, which can be distinguished by the larvae in the field. Unfortunately, laboratory assays expose larvae to high concentrations of the chemical cues that may induce unnatural metamorphosis (Zimmer \& Butman 2000). This may explain why the larvae metamorphose in response to a broader range of corals than they consume.

The water-soluble settlement cue from Porites compressa that induces metamorphosis in Phestilla sibogae is well studied, but is not chemically described (Hadfield \& Scheuer 1985, Hadfield \& Pennington 1990). Other Phestilla spp. studied also respond to a watersoluble metamorphic inducers (R.R.-W. \& S.S. unpubl. data). The specificity of adult $P$. minor and Phestilla sp. 1 to 1 or 2 coral species suggests that Porites spp. are producing distinctive and recognizable settlement cues. Phestilla sp. 2 also distinguishes among coral species in the same genus. Neural pathways are known to increase sensitivity to chemical cues in specific hosts for insects (Hay \& Steinberg 1992, Bernays \& Wcislo 1994), and are implicated in the ability of $P$. sibogae to recognize chemical cues in corals (Murphy \& Hadfield 1997, Hadfield et al. 2000). To better understand the developmental biology and cellular process of metamorphosis in Phestilla spp., it is important to describe the chemical cues responsible for metamorphosis.

Host chemistry is an important ecological aspect of specialization for many terrestrial insects and marine invertebrates (Ehrlich \& Murphy 1988, Hay et al. 1990, Hay 1992, Stachowicz \& Hay 2000). For insects the chemical features of the host are selected by the mother, who locates an appropriate site for oviposition. For marine larvae, including Phestilla spp., host chemistry may serve as a cue for larval recruitment to the appropriate habitat. Many marine invertebrates rely on chemically defended hosts for refuge and as a source of deterrent secondary metabolites (Hay et al. 1990, Cimino \& Sodano 1994, Becerro et al. 2001, Cruz-Rivera \& Paul, in review). Predator avoidance, response to specific metamorphic inducers, and larval life-history together have probably influenced specialization in Phestilla nudibranchs. 
Acknowledgements. The help of the University of Guam Marine Laboratory students, faculty, and staff is gratefully acknowledged. Corals were collected in accordance with the Guam Department of Aquatic Wildlife and Resources regulations. Special thanks to Richard Randall (corals), Clay Carlson (nudibranchs), and Bill Rudman (nudibranchs) for their help with taxonomy. We would like to thank Michael Hadfield for his helpful advice regarding research on Phestilla spp. Thanks also to Pat and Lori Colin and the staff at the Coral Reef Research Foundation for their help while visiting Palau. Helpful comments by Clay Carlson, Edwin Cruz-Rivera, Robert Thacker, and 3 anonymous reviewers improved the manuscript. This work was supported by NSF grant OCE9911867 to V. Paul, and is University of Guam Marine Laboratory contribution no. 532 and Smithsonian Marine Station at Fort Pierce contribution no. 564.

\section{LITERATURE CITED}

Becerro M, Goetz G, Paul VJ, Scheuer P (2001) Chemical defenses of the sacoglossan mollusk Elysia rufescens and its host alga Bryopsis sp. J Chem Ecol 27:2287-2299

Berenbaum MR (1996) Introduction to the symposium: on the evolution of specialization. Am Nat 148(Suppl):78-83

Bernays EA, Graham M (1988) On the evolution of host specificity in phytophagous arthropods. Ecology 69: 886-892

Bernays EA, Wcislo WT (1994) Sensory capabilities, information processing, and resource specialization. Q Rev Biol 69:187-204

Browne KA, Zimmer RK (2001) Controlled field release of a waterborne chemical signal stimulates planktonic larvae to settle. Biol Bull (Woods Hole) 200:87-91

Cimino G, Sodano G (1994) Transfer of sponge secondary metabolites to predators. In: van Soest, van Kampen, Braekman (eds) Sponges in time and space. Balkema, Rotterdam, p 459-472

Ehrlich PR, Murphy DD (1988) Plant chemistry and host range in insect herbivores. Ecology 69:908-909

Feder JL, Bush GL (1989) A field test of different host-plant usage between two sibling species of Rhagoletis pomonella fruit flies (Diptera: Tephritidae) and its consequences for sympatric models of speciation. Evolution 43: 1813-1819

Funk DJ, Futuyma DJ, Orti G, Meyer A (1995) A history of host associations and evolutionary diversification for Ophraella (Coleoptera: Chrysomelidae): new evidence from mitochondrial DNA. Evolution 49:1008-1017

Futuyma D, Moreno G (1988) The evolution of ecological specialization. Annu Rev Ecol Syst 19:207-233

Gibson GD, Chia FS (1995) Developmental variability in the poecilogonous opisthobranch Haminaea callidegenita: life-history traits and effects of environmental parameters. Mar Ecol Prog Ser 121:139-155

Ginsburg D, Paul V (2001) Chemical defenses in the sea hare Aplysia parvula: importance of diet and sequestration of algal secondary metabolites. Mar Ecol Prog Ser 215: 261-274

Gosliner T (1992) Biodiversity of tropical opisthobranch gastropod faunas. In: Richmond RH (ed) Proc 7th Int Coral Reef Symp, Vol 2, University of Guam, Mangilao, p 702-709

Gosliner T, Behrens D, Williams G (1996) Coral reef animals of the Indo-Pacific. Sea Challengers, Monterey

Hadfield MG (1977) Chemical interactions in larval settling of a marine gastropod. In: Faulkner DJ, Fenical WH (eds)
Marine natural products chemistry. Plenum Press, New York, p 403-413

Hadfield MG, Pennington JT (1990) Nature of the metamorphic signal and its internal transduction in larvae of the nudibranch Phestilla sibogae. Bull Mar Sci 46:455-464

Hadfield MG, Scheuer D (1985) Evidence for a soluble metamorphic inducer in Phestilla: ecological, chemical and biological data. Bull Mar Sci 37:556-566

Hadfield MG, Meleshkevitch EA, Boudko DY (2000) The apical sensory organ of a gastropod veliger is a receptor for settlement cues. Biol Bull (Woods Hole) 198:67-76

Hall SJ, Todd CD, Gordon AD (1982) The influence of ingestive conditioning on the prey species selection in Aeolidia papillosa (Mollusca: Nudibranchia). J Anim Ecol 51: 907-921

Harris LG (1973) Nudibranch associations. In: Cheng TC (ed) Current topics in comparative pathobiology, Vol 2. Academic Press, New York, p 213-315

Harris LG (1975) Studies on the life history of two coral-eating nudibranchs of the genus Phestilla. Biol Bull (Woods Hole) 149:539-550

Hay ME (1992) The role of seaweed chemical defenses in the evolution of feeding specialization and in the mediation of complex interactions. In: Paul V (ed) Ecological roles of marine natural products. Comstock Publishing, Ithaca, NY, p 93-118

Hay ME, Steinberg PD (1992) The chemical ecology of plantherbivore interactions in marine versus terrestrial communities. In: Rosenthal G, Berenbaum M (eds) Herbivores their interactions with secondary plant metabolites, Vol 2. Academic Press, San Diego, p 371-413

Hay ME, Duffy JE, Fenical W (1990) Host-plant specialization decreases predation on a marine amphipod: an herbivore in plant's clothing. Ecology 71:733-743

Knowlton N (1993) Sibling species in the sea. Annu Rev Ecol Syst 24:189-216

Knowlton N (2000) Molecular genetic analyses of species boundaries in the sea. Hydrobiologia 420:73-90

Krug PJ (2001) Bet-hedging dispersal strategy of a specialist marine herbivore: a settlement dimorphism among sibling larvae of Alderia modesta. Mar Ecol Prog Ser 213:177-192

Krug PJ, Manzi A (1999) Waterborne and surface-associated carbohydrates as settlement cues for larvae of the specialist marine herbivore Alderia modesta. Biol Bull (Woods Hole) 197:94-103

Lambert WJ, Todd CD (1994) Evidence for a water-borne cue inducing metamorphosis in the dorid nudibranch mollusc Adalaria proxima (Gastropoda: Nudibranchia). Mar Biol 120:267-271

Leebens-Mack J, Pellmyr O, Brock M (1998) Host specificity and the genetic structure of two yucca moth species in a yucca hybrid zone. Evolution 52:1376-1382

Miller SE, Hadfield MG (1986) Ontogeny of phototaxis and metamorphic competence in larvae of the nudibranch Phestilla sibogae Bergh (Gastropoda: Opisthobranchia). J Exp Mar Biol Ecol 97:95-112

Morse AN, Iwao K, Baba M, Shimoike K, Hayashibara T, Omori M (1996) An ancient chemosensory mechanism brings new life to coral reefs. Biol Bull (Woods Hole) 191: 149-154

Murphy BF, Hadfield MG (1997) Chemoreception in the nuibranch gastropod Phestilla sibogae. Comp Biochem Physiol A 118: 727-735

Pawlik JR (1992) Chemical ecology of the settlement of benthic marine invertebrates. Oceanogr Mar Biol Annu Rev 30:273-335

Randall RH (2003) An annotated checklist of hydrozoan and 
scleractinian corals collected from Guam and other Mariana Islands. Micronesica 35/36:121-137

Robertson R (1970) Review of the predators and parasites of stony corals, with special reference to symbiotic prosobranch gastropods. Pac Sci 24:43-54

Rudman WB (1981) Further studies on the anatomy and ecology of opisthobranch molluscs feeding on the scleractinian coral Porites. Zool J Linn Soc 7:373-412

Schultz JC (1988) Many factors influence the evolution of herbivore diets, but plant chemistry is central. Ecology 69: 896-897

Shjegstad SM (2002) Settlement and metamorphosis preferences of larvae of the corallivorous nudibranch Phestilla minor. MS thesis, University of Guam, Mangilao

Stachowicz JJ, Hay ME (2000) Geographic variation in camouflage specialization by a decorator crab. Am Nat 156: $59-71$

Trowbridge CD (1991) Diet specialization limits herbivorous sea slug's capacity to switch among food species. Ecology 72:1880-1888

Trowbridge CD (2000) The missing links: larval and postlarval development of the ascoglossan opisthobranch

Editorial responsibility: Charles Birkeland (Contributing Editor), Honolulu, Hawaii, USA
Elysia viridis. J Mar Biol Assoc UK 80:1087-1094

Trowbridge CD, Todd CD (2001) Host-plant change in marine specialist herbivores: ascoglossan sea slugs on introduced macroalgae. Ecol Monogr 71:219-243

Wieczorek SK, Todd CD (1998) Inhibition and facilitation of settlement of epifaunal marine invertebrate larvae by microbial biofilm cues. Biofouling 12:81-118

Williams SI, Walker DI (1999) Mesoherbivore-macroalgal interactions: feeding ecology of sacoglossan sea slugs (Mollusca, Opisthobranchia) and their effects on their food algae. Oceanogr Mar Biol Annu Rev 37:87-128

Williamson JE, DeNys R, Kumar N, Carson DG, Steinberg PD (2000) Induction of metamorphosis in the sea urchin Holopneustes purpurascens by a metabolite complex from the algal host Delisea pulchra. Biol Bull (Woods Hole) 198: $1-14$

Zimmer R, Butman C (2000) Chemical signaling processes in the marine environment. Biol Bull (Woods Hole) 198: $168-187$

Zimmer-Faust RK, Tamburri MN (1994) Chemical identity and ecological implications of a waterborne, larval settlement cue. Limnol Oceanogr 39(5):1075-1087

Submitted: July 17, 2002; Accepted: March 12, 2003

Proofs received from author(s): June 12, 2003 